\title{
Ascus Cytology and Ascocarp Development in Achaetomiella virescens
}

\author{
J. N. Rai, A. Saxena (Miss) and H. J. Chowdhury \\ Mycology and Plant Pathology Laboratory, Botany Department, \\ Lucknow University, Lucknow, India
}

Received May 10, 1977

The genus Achaetomiella v. Arx is a recent addition to the order Chaetomiales and so far only 2 species viz., $A$. virescens v. Arx and A. megaspora (Sörgel) D. Hawksw. have been described (von Arx 1970, D. Hawksw. 1975). The genus Achaetomiella shows close resemblance with the genus Chaetomium rather than Achaetomium as it possess perithecia which have hairy ornamentation or setae (D. Hawksw. 1975). However, from Chaetomium it differs primarily in lacking the terminal hairs. The homothallic genus Achaetomiella is so far uninvestigated as to the development of ascocarp and the nuclear behaviour in its ascogenous system, hence both the species of the genus $A$. virescens and $A$. megaspora have been investigated in this laboratory. The present paper embodies the detailed account of the development of ascocarp and the ascus cytology of Achaetomiella virescens.

\section{Materials and methods}

Achaetomiella virescens v. Arx (CBS/148.68) formed abundant perithecia on oat meal agar. For the early stages of ascocarp development the fungus was grown on sterilized microscope slides having a thin film of oat meal agar medium. These slides were placed in moist chambers and incubated at $28 \pm 1^{\circ} \mathrm{C}$, fixed at different time intervals for the desired stage of ascocarp development. These slides were examined under the microscope after staining with aceto-iron haematoxylin. For the morphological study of young and mature ascocarps the fungus was grown on oat meal agar and was subjected to microtome sectioning for internal details.

For the nuclear divisions in the developing ascus and ascospore, squash preparations were made with acetocarmine after fixing the perithecia in absolute alcohol: glacial acetic acid (3: 1) solution for 24 hrs.

\section{Observations}

\section{Development of ascocarp}

The fungus produces abundant aerial mycelium on oat meal agar. The hyphae are septate and multinucleate. The mycelium shows frequent hyphal anastomosis and fusion.

The ascocarp develops from a distinct, stout lateral branch designated as the ascogonium, from the basal mycelium, which has 2-8 nuclei with dense cytoplasm. 

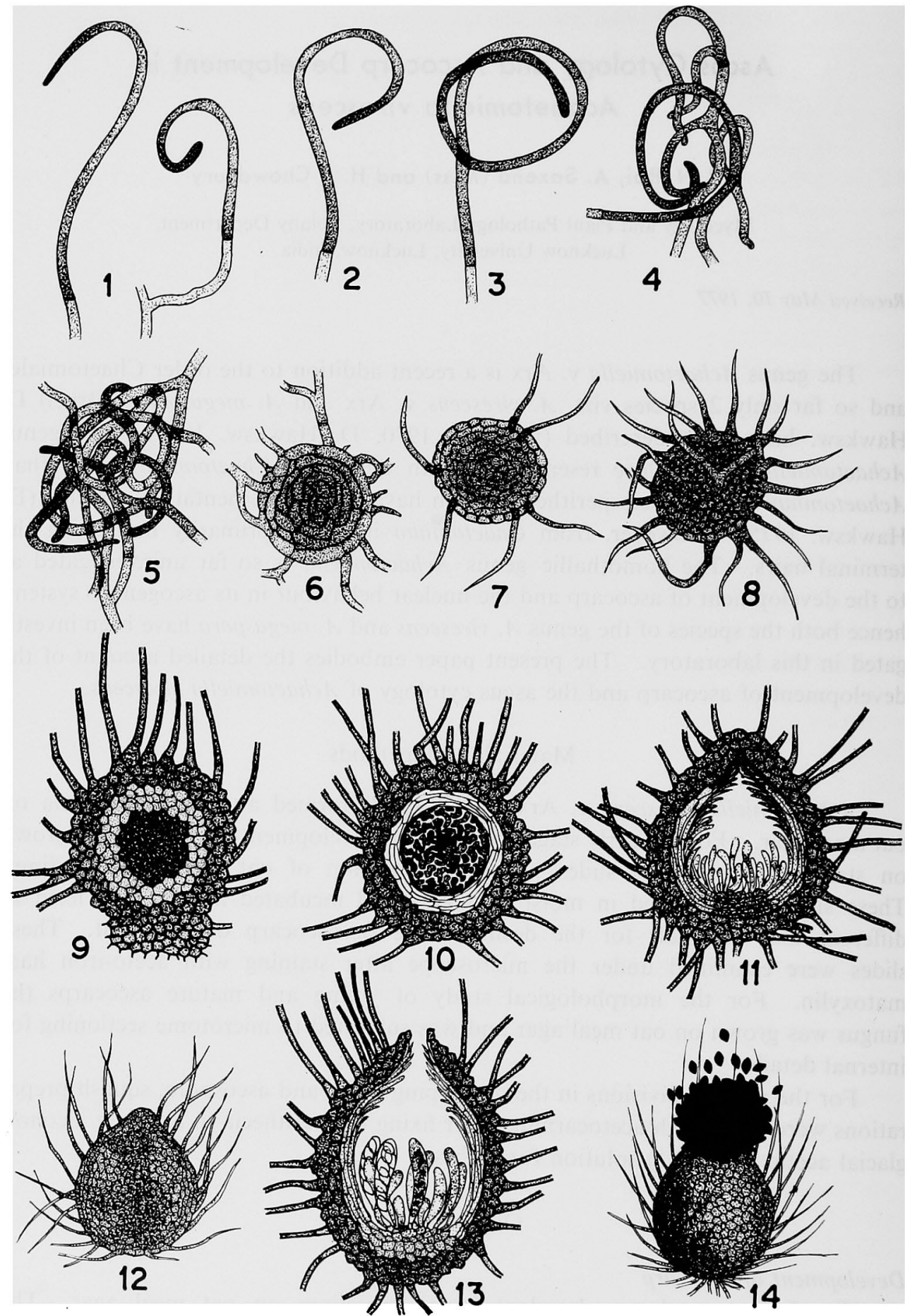

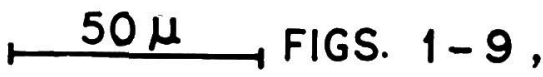

$100 \mu$

FIGS. 10, 11\&13, $200 \mu$ FIGS. 12 \& 14. 
The ascogonium is separated by a septum at the base from rest of the mycelium (Fig. 15). The tip of the ascogonium elongates and becomes a hook like structure (Figs. 1,2), further growth of this hook leads into the formation of a septate coil (Figs. 3, 16). While the ascogonial coil is developing, additional specialized hyphal branches, originate from the adjacent mycelial cells and from the proximal cells of the coil (Figs. 4, 5). These branches ramify round the ascogonial coil forming the perithecial walls and subsequently the perithecial hairs (Figs. 6, 7, 8, 17, 18). At this stage the ascocarp initial is clearly distinguishable into 2 distinct zones, the outer wall layer and the inner central core (Figs. 9, 19) which later develops into the sporogenous system. Further development of the wall differentiates it into two distinct layers, the outer layer which is composed of thick walled dark coloured polygonal cells about 2 to 3 cells thick and the inner contains thin walled hyaline tangentially elongated cells (Figs. 10, 20). Soon after the formation of wall layers the central core start dividing in all the directions and becomes the sporogenous tissue. Now the sporogenous tissue breaks and becomes a loose mass of multinucleate cells (Figs. 10, 20). Meanwhile the inward growth of inner wall layer cells in the upper region of the ascocarp compresses the multinucleate cells of the central core towards the base resulting in the downward movement of sporogenous cells (Figs. 11, 21). Some of these multinucleate cells become meristematic and produce binucleate ascogenous cells, later from which the croziers develop. The young asci originate as a basal tuft or fascicle (Fig. 22) from the conical mass of ascogenous cells. In association with the asci occur paraphyses.

As the ascocarp ages the innerwall cells and the periphyses disappear to form an opening in the upper region of the ascocarp opposite to the ascogenous cells which is internally lined by the remaining periphyses and it opens to the exterior by an ostiole (Figs. 13,23). The paraphyses in the later stages of ascus development disintegrate.

\section{Development of ascus and ascospores}

Ascus in $A$. virescens originates from the binucleate cells of the ascogenous system (Fig. 40). First one of such binucleate cells from the ascogenous system elongates and simultaneously, the two nuclei divide mitotically resulting into the formation of 4 daughter nuclei (Fig. 40A, B). The tip of this cell bends to form a crozier (Figs. 40B, 24). Two septa are laid down resulting in a fully developed crozier consisting of three cells (Fig. 40D), the antipenultimate cell with a single nucleus, the penultimate cell with two nuclei and the bent ultimate cell with single nucleus. The ultimate cell grows further downwards and it comes in contact with antipenultimate cell. Soon the cell wall at the point of contact dissolves and the nucleus from the ultimate cell is released into the antipenultimate cell. Thus, the antipenultimate cell becomes binucleate again. The two nuclei of this cell divide again and may give rise to a crozier. Repeated occurrence of this procedure

Figs. 1-14. Stages of ascocarp development in $A$. virescens. 1-5, ascogonial coil. 6-7, ascocarp initials. 8, young ascocarp. 9, vertical longitudinal section of young ascocarp differentiated into central sporogenous core and pseudoparenchymatous peridium. 10, division and breaking in sporogenous core. 11, development of basal ascogenous system and young periphyses. 12-13, fully developed ascocarp. 14, mature ascocarp. 

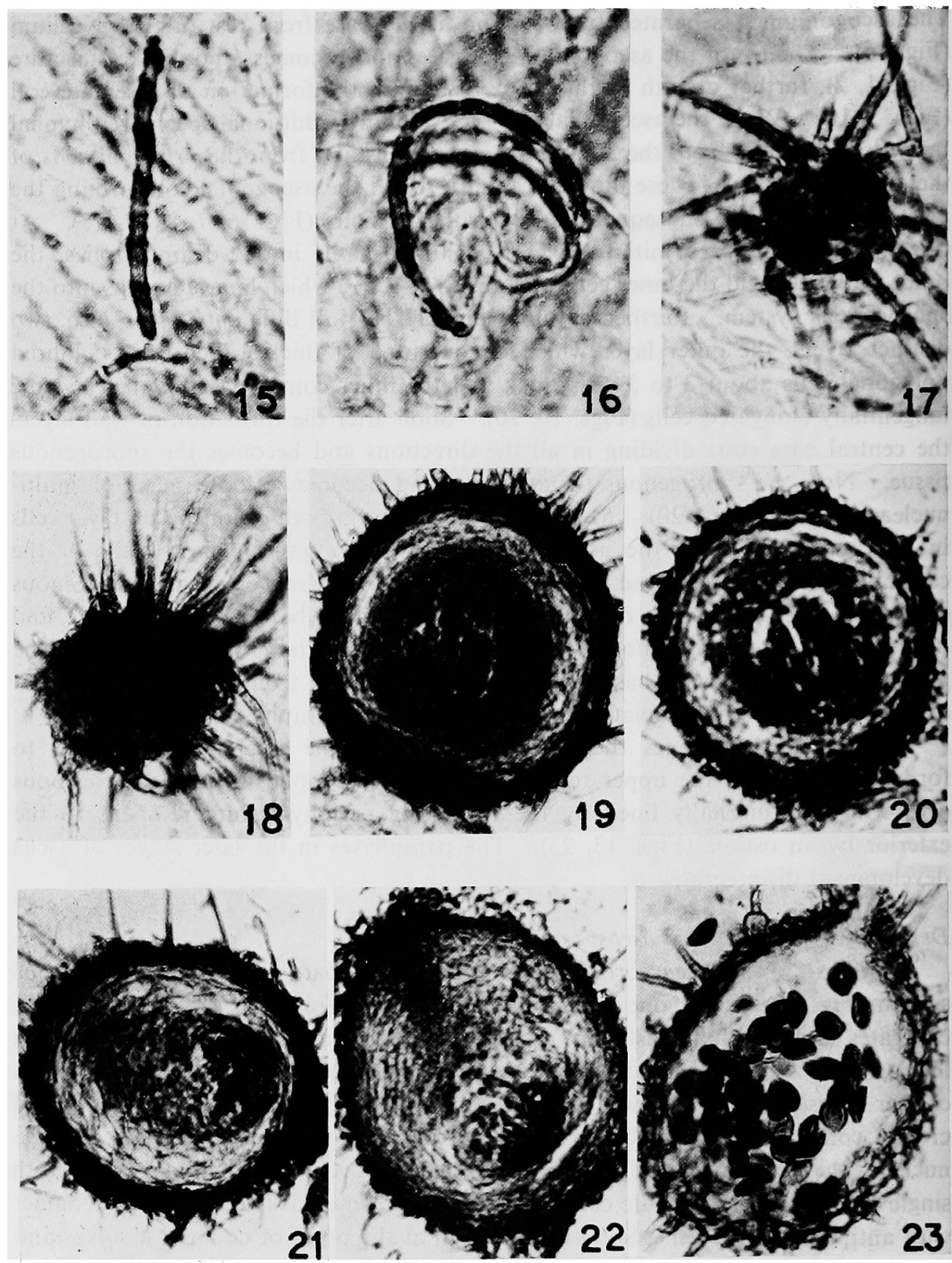

Figs. 15-23. Stages of ascocarp development in A. virescens. 15 , ascogonial initial. $\times 600.16$, ascogonial coil. $\times 550$. 17 , ascocarp initial. $\times 550$. 18 , young ascocarp. $\times 500.19$, young ascocarp differentiated into central sporogenous core and pseudoparenchymatous peridium. $\times 650$. 20 , breaking of the central core. $\times 650$. 21, dissolution of the central cells. $\times 600$. 22, formation of ostiole. $\times 650$. 23, vertical longitudinal section of mature ascocarp. $\times 450$. 
results in the formation of a cluster of croziers. The two nuclei of the penultimate cell fuse, forming the ascus mother cell containing a prominent diploid nucleus (Figs. 40C, D). This stage corresponds to Fig. 10 showing the development of ascocarp.

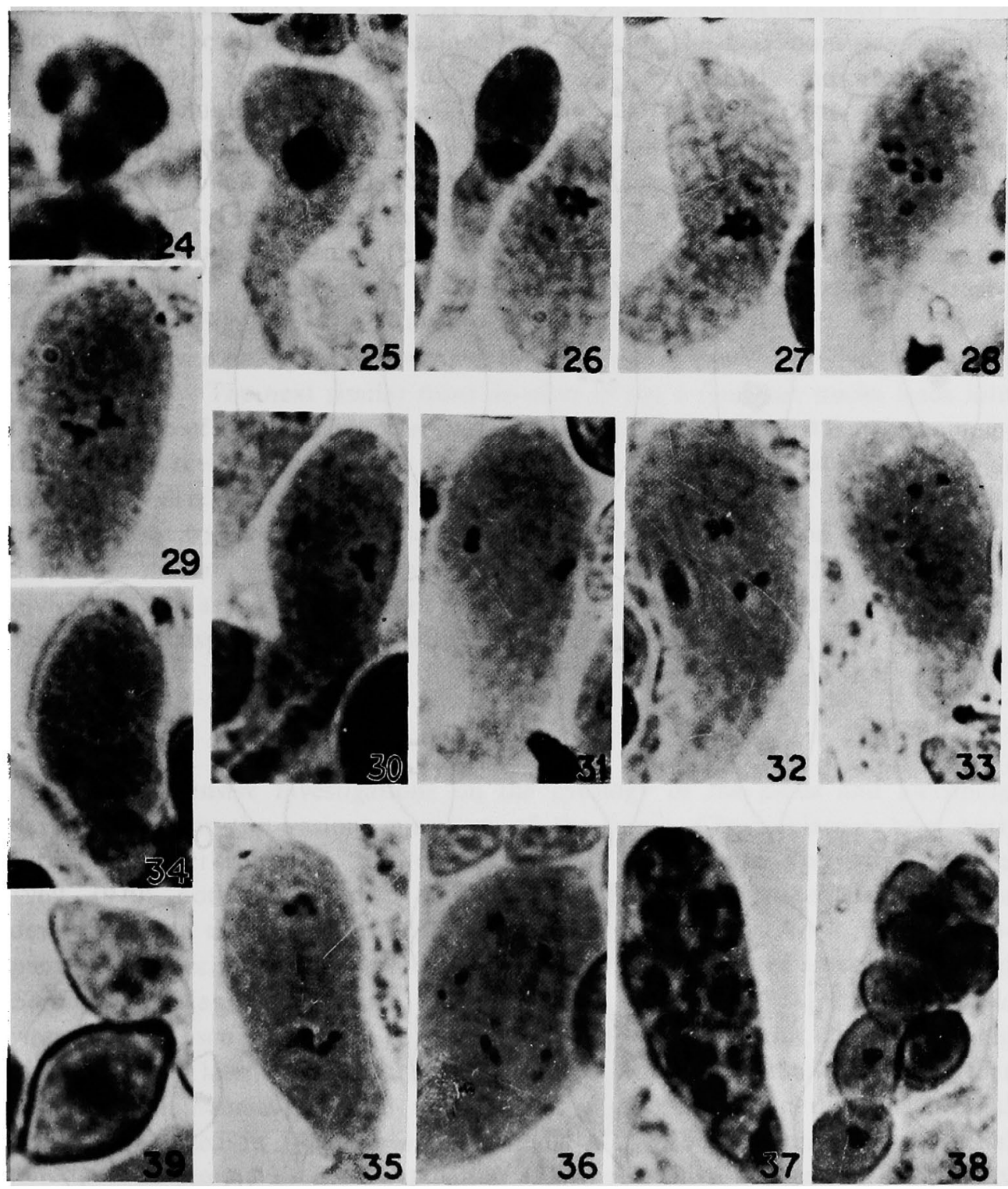

Figs, 24-39. Stages in the ascus and ascospore development in A. virescens. 24, crozier at conjugate division. $\times 2000$. $25-26$, young ascus. $25, \times 2600,26, \times 25000.27$, diplotene. $\times 2200$. 28, metaphase I. $\times 2200$. 29, anaphase I $\times 2500$. 30 , telophase I. $\times 2200.31$, metaphase II. $\times 2200$. 32, anaphase II. $\times 2500$. 33, telophase II. $\times 2000$. 34 , metaphase III. $\times 2000.35$, anaphase III. $\times 2200$. 36 , telophase III. $\times 2500$. 37, eight nucleate ascus showing cleavage in the cytoplasm. $\times 2200.38$, ascus with eight ascospores. $\times 1650$. 39, young binucleate and mature uninucleate ascospores, $\times 2900$. 
The penultimate cell elongates vertically and expands transversely to form the future ascus (Fig. 25).

Soon after the fusion of the nuclei of penultimate cell the resulting diploid
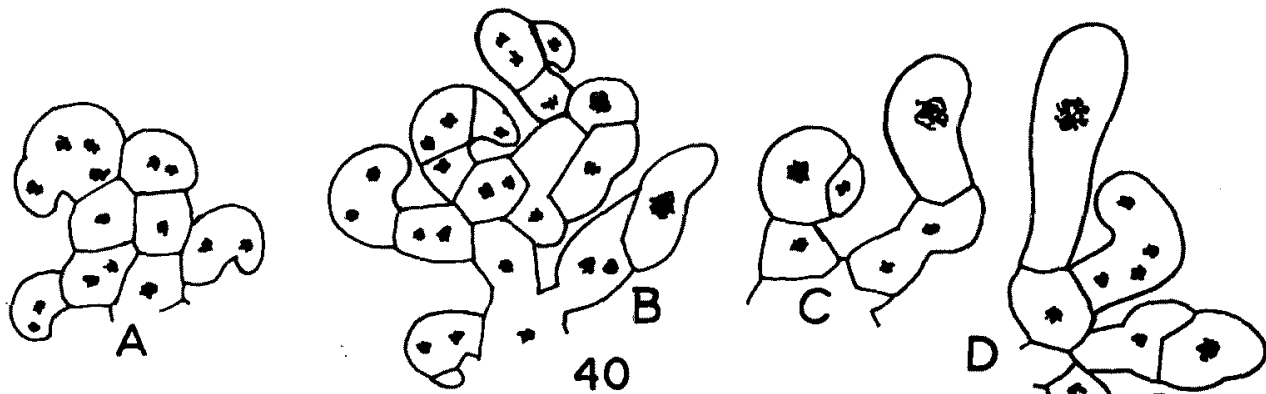

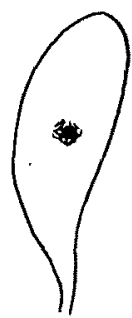

41

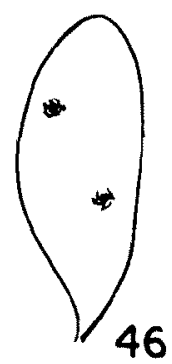

46

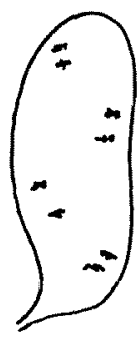

52

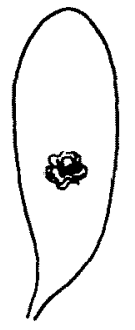

42

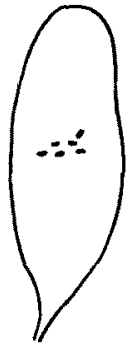

43

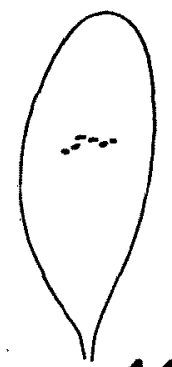

44
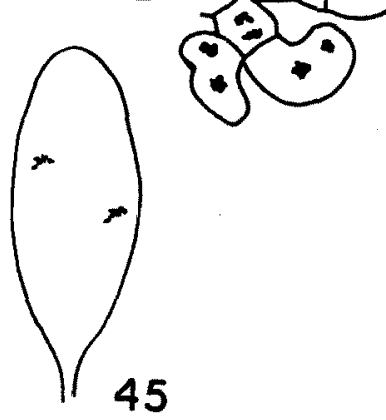
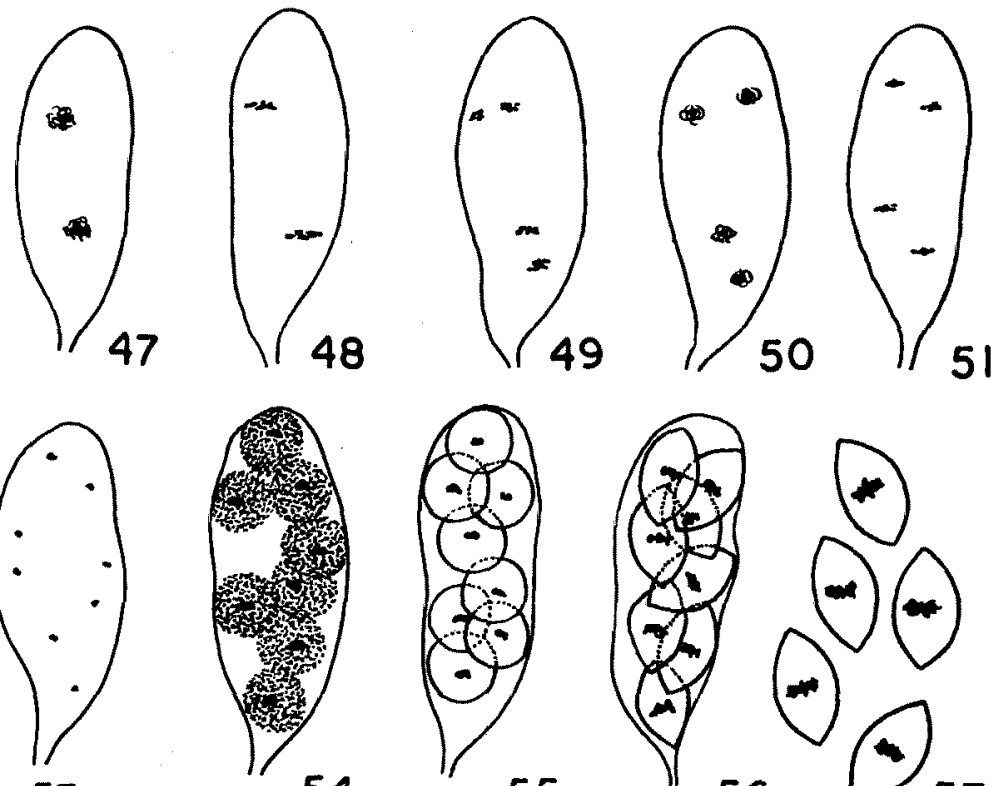

54

55
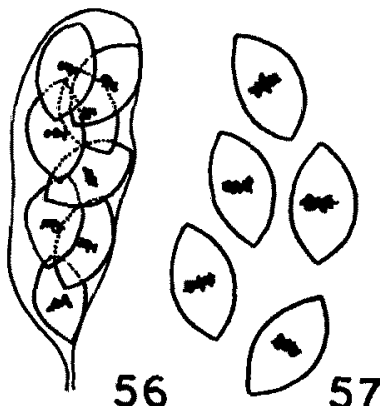

Figs. 40-57. Diagrams showing stages of the ascus and ascospore development in A, virescens. 40 (A-D), different stages of division in the crozier and formation of young asci. 41, young ascus. 42, prophase. 43, diakinesis. 44, metaphase I. 45, anaphase I, 46, telophase I. 47, prophase. 48, metaphase II. 49, anaphase II. 50, telophase II. 51, metaphase III. 52, anaphase III. 53, telophase III. 54-55, formation of ascospores. 56, eight ascospores in the ascus. 57, ascospores. 
nucleus enters meiotic division. During the first nuclear division the nucleus is seen in the centre of the young ascus with a large deeply stained nucleolus and less densely stained chromatin material (Figs. 25, 41).

At pachytene the chromosomes become somewhat distinct but not countable (Figs. 26, 42). In diplotene the paired chromosomes were seen in the form of chromatin blocks (Figs. 27, 43). At metaphase I, 6 bivalents arranged in a plate were seen in the form of dark stained dots showing the maximum condensation (Figs. 28, 44). Six condensed dots at metaphase I clearly indicate that the chromosome number of the fungus is $(n=6)$. Anaphase I (Figs. 29, 45) was followed by telophase $I$ in which two daughter nuclei may be seen in the young ascus (Figs. 30, 46). After the completion of first division the nuclei show interphase. At this stage 2 nuclei characterized by slightly stained chromatin material and deeply stained nucleolus (Fig. 47). After interphase these nuclei enter the second division. At metaphase II, two plates are formed each with 6 condensed chromosomes (Figs. 31, 48). At anaphase II, four groups of 6 chromatids move towards opposite pole (Figs. 32, 49) and the telophase II results in 4 daughter nuclei (Figs. 33, 50). The next similar third division of the 4 daughter nuclei leads into the formation of 8 daughter nuclei (Figs. 34, 35, 36, 51, 52, 53). After the completion of third division the nuclear membrane did not appear and the deposition of ascospore wall is initiated around each daughter nuclei (Figs. 37, 54). Soon the walls of ascospores become distinct and 8 uninucleate ascospores can be seen (Figs. 38, 55). The mature ascospores have a single large nucleus (Figs. 39, 57). Fourth division in the ascospores was not frequently observed during this study however, rarely few ascospores were seen with 2 nuclei (Fig. 39).

\section{Discussion}

While extensive investigations on the cytology of the ascus and ascospore development for the various members of the family Chaetomiaceae have been carried out (Berkson 1966, Brewer and Duncan 1968, Ranga Rao and Mukerjee 1969,1970 ), nothing is known about the cytology of the ascus and ascospore development in the recently established genus Achaetomiella v. Arx. The development of perithecium in Achetomiella is almost similar to that of Achaetomium and Sordaria (Rai and Chowdhury 1973, Carr and Olive 1958). In Achaetomiella virescens the ascogonial coil generally originates from a stout, deeply staining multinucleated lateral branch from the basal creeping mycelium and by further elongation it assumes a coiled shape. This ascogonial coil never coils around itself as reported in Chaetomium (Whiteside 1957, 1961) where the ascogonial hyphae coils around itself by elongation and appears like a spring of 4-8 closely arranged rings. In $A$. virescens plasmogamy (Fig. 4) occurs after the formation of the first branch and is by the fusion of a hyphal branch from the terminal portion of the inner coil with the other hyphal cell as reported for various other ascomycetes -viz. Achaetomium, Gelasinospora, Neurospora and Sordaria (Rai and Chowdhury 1973, Ellis 1960, Colson 1934, Carr and Olive 1958). From the main hypha the ascogonial hypha originates, and from the basal or lower cells of the ascogonial 
hyphae arise outgrowths that invest the coil and subsequently develops the pseudoparenchymatous wall of the perithecium. The multinucleate cells of the central core give rise to binucleate ascogenous hyphae which develop into croziers. The ascus develops from the penultimate cell of the crozier. The nuclear behaviour during the ascus and ascospore development is similar to that of many investigated members of ascomycetes (Singleton 1953, Rogers 1965, Lu 1967, Rao and Mukerjee 1969, 1970).

All the sequential stages in ascus development, i.e. uninucleate, binucleate, four nucleate and eight nucleate stages were frequently observed in the present investigation. The mature ascospores are uninucleate.

\section{Acknowledgement}

The authors are thankful to Dr. R. A. Samson (Centraalbureau Voor Schimmelcultures-BAARN, Netherlands) for providing the viable culture of Achaetomiella virescens for the study.

\section{Summary}

The development of ascocarp and the nuclear behaviour during the development of ascus and ascospores was studied in Achaetomiella virescens. The ascocarp development in $A$. virescens begins with the formation of deeply staining ascogonial coils as lateral branches of the vegetative hyphae. As these coils develop into multicellular, multinucleate ascogonia, they are surrounded by a pseudoparenchymatous envelope. This ascocarp initial in later stages of development gets differentiated into a central sporogenous core and wall layers. The central sporogenous core breaks and becomes a loose mass of multinucleate cells. Some of these multinucleate cells become meristematic and give rise to ascogenous cells at the base of developing ascocarp. Asci are formed from these ascogenous cells by croziers. Four divisions result in binucleate ascospores and each mature ascospore has a single nucleus. The haploid number of chromosome is $6(n=6)$.

\section{References}

Berkson, B. M. 1966. Cytomorphological studies of the ascogenous hyphae of four species of Chaetomium. Mycologia 58: 125-130.

Brewer, D. and Duncan, J. M. 1968. Cytological studies of Chaetomium cochliodes. Can. J. Bot. 46: 773-775.

Carr, A. J. H. and Olive, L. S. 1958. Genetics of Sordaria fimicola II. Cytology. Am. J. Bot. 45: $142-150$.

Colson, B. 1934. The cytology and morphology of Neurospora tetrasperma Dodge. Ann. Bot. 48: 211-224.

Ellis, J. J. 1960. Plasmogamy and ascocarp development in Gelasinospora calospora. Mycologia 52: 557-573.

Hawksworth, D. L. 1975. Achaetomiella megaspora the correct name for A. fusispora. Trans. Br. Mycol. Soc. 65 (1): 136-137.

Lu, B. C. 1967. The course of meiosis and centriole behaviour during the ascus development of Gelasinospora calospora. Chromosome 22: 210-226. 
Rai, J. N. and Chowdhury, H. J. 1973. Cytology of the ascus and ascocarp development in Achaetomium uniapiculatum. J. Gen. Appl. Microbiol. 19: 481-490.

Ranga Rao, V. and Mukerji, K. G. 1969. Cytology of ascus development in the genus Chaetomidium. Can. J. Bot. 47: 869-871.

- and -. 1970. Cytology of the ascus in Ascotricha guamensis. Mycologia 62: 301-306.

Rogers, J. D. 1965. Hypoxylon fuscum L. Cytology of the ascus. Mycologia 57: 789-803.

Singleton, J. R. 1953. Chromosome morphology and the chromosome cycle in the ascus of Neurospora crassa. Am. J. Botany 40: 124-144.

von Arx. 1970. The genera of Fungi sporulating in pure culture, 288 page 134 figs. Ed. J. Cramer, Germany.

Whiteside, W. C. 1957. Perithecial initials of Chaetomium. Mycologia 49: 420-425.

- 1961. Morphological studies in Chaetomiaceae. Mycologia 53: 512-523. 